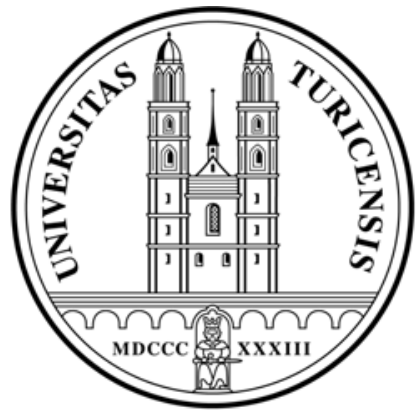

Institute for Empirical Research in Economics

University of Zurich

Working Paper Series

ISSN 1424-0459

Working Paper No. 514

\title{
Democracy and Innovation
}

Bruno S. Frey

October 2010 


\title{
Democracy and Innovation
}

\author{
by \\ Bruno S. Frey \\ University of Warwick \\ and \\ University of Zurich*
}

(27 September 2010)

\section{Democracy is a dynamic idea}

Democracy is one of the great ideas of mankind. The principle that people govern themselves is far from trivial but rather surprising. It seems that for hundreds, if not thousands, of years the natural order in the public sphere was an authoritarian and often dictatorial rule. Today, self-determination in politics has become the ideal everybody accepts. This is reflected in the fact that even dictators and authoritarian rulers make a great effort to appear democratic. Not rarely, regimes that suppressed any idea of self-determination of their citizens, explicitly called themselves „democracies“. The German Democratic Republic is a case in point.

The virtually general acceptance of democracy as the only legitimate form of government has its downside. Democracy has become "sacred", i.e. has reached a position in which criticism is ill considered. It appears that once a "democratic state" (irrespective of whether it deserves that name or not) has been achieved, the ideal has been reached and no changes and further developments are considered.

I wish to argue in this paper that such a contentment undermines the very idea of democracy which I see as a dynamic concept which should be open to criticism and change. In particular, I consider two possible developments:

(a) More political power should be given to the citizens, and perhaps to other members of the population. Representative democracy was a great achievement but direct democracy is the appropriate form of democracy for the $21^{\text {st }}$ century.

(b) Many innovations are possible in democracy. I shall mention a few but want to focus on the potential role of random mechanisms to secure that the population is more fully represented in the political process both with respect to the persons in politics and the decisions taken.

\footnotetext{
* The author is Distinguished Professor of Behavioural Science, Warwick Business School, University of Warwick, UK, and Professor of Economics, University of Zurich. He is also Research Director of CREMA - Center for Research in Economics, Management and the Arts, Switzerland.

Mailing address: Institute for Empirical Research in Economics, University of Zurich, Wilfriedstrasse 6, CH-8032 Zurich, Switzerland

e-mail: bsfrey@iew.uzh.ch.
} 
Section II sketches the tree major stages of democracy and section III deals with the fundamental problems of democracy and of other organizations. Referendum democracy is discussed in section IV, including its strengths and weaknesses. The following section asks why there are so few Referendum Democracies. Section VI mentions some innovative extensions of democracy with respect to voting rules and procedures. Section VII lists some innovations beyond traditional democracy, in particular the use of random mechanisms such as probability voting and demarchy. The last section offers conclusions.

\section{Three stages of democracy}

After hundreds and thousands of years of authoritarian and dictatorial regimes direct democracy appeared in classical Athens. Despite its well-known limitations (in particular that a large share of the population was excluded from political participation) this was an extraordinary achievement. It took a long time until the French revolution introduced representative democracy in order to allow a large population to participate in political affairs. The third stage of democracy is based on direct participation rights of the citizens via popular referenda. This establishes the citizens' position as the sovereign which has the last word.

The advent of each of these stages can be considered a social innovation of great importance. The following three sections discuss the last stage of referendum democracy compared to the representative elements as they still exist in most democracies in the world.

\section{Fundamental problems of democracy}

Democracy can be looked at in terms of a principal agent problem as it exists in all institutions. The principal is the owner of the organization and wants to reach specific goals. The agents are supposed to fulfil these goals but they have their own goals they want to reach. There is thus an inherent conflict between the interests of the principals and the agents. In a democracy, the citizens are the principals, and the (professional) politicians are the agents supposed to act in the interests of the citizens.

In fact, the politicians often behave as if they were the masters, and they often take it for granted that the citizens have to follow what they order. A realistic model of the politicians' behaviour assumes that politicians have four goals: they want to exert power over the citizens; they want to be recognized or even loved by the population; they often wish to pursue a certain ideology; and they are interested in gaining income. The goals pursued by politicians are thus not different from other people. Politicians in democracies are subject to a re-election constraint. They can only stay in power if they get sufficient support from the voters. Another constraint is the outbreak of scandals which sometimes force politicians to give up their position when the pressure from the citizens become intensive. Politicians should not be seen as being directly interested in the welfare of their citizens (though, of course, they claim to do so); rather, if the re-election and scandal constraints are strong enough, politicians are forced to follow the citizens' wishes.

The citizens in a representative democracy are severely limited in influencing the behaviour of politicians. Essentially, they can only make their wishes felt at election time, normally all four or five years. The citizens in referendum democracies have a much larger set of instruments available to assert their wishes. Of course, in no referendum democracy the citizens take all political decisions. There is a parliament and a government as is the case in a representative democracy. The crucial difference is that neither parliament nor government has the power to take a final decision. In all 
matters the citizens are the sovereign who has the last say. The instruments consist in obligatory referenda (for constitutional changes and major decisions); optional referenda (for less important issues, depending on a sufficient number of citizens wanting to have a referendum); popular initiatives which force parliament and government to hold a referendum; and recall allowing voters to force executive politicians to resign if they are deemed to do a bad or dishonourable job.

The instruments of (semi-) direct democracy should not be seen in terms of a mechanistic process in which the citizens tell the politicians what to do. Rather, referendum democracy is characterized by an intensive discursive process between citizens and politicians. This takes place before a referendum where the politicians have to make an effort to inform the citizens and to convince them that the course of action they take is in the interests of the citizens. Often, the voters agree and support the actions designed by parliament and government. In Switzerland there are many cases in which the citizens approved that they are more highly taxes if they felt that the money needed is well spent. However, quite often the citizens do not follow the course the politicians want not least because they see or at least sense that the actions are more in the interests of the "political class" rather than of the citizens.

\section{Referendum democracy}

There are a few countries with significant elements of direct democracy, in particular Australia. A large share of American States (but not the US national state) has referenda, initiatives and recall, such as for instance Oregon ${ }^{1}$. Some European states have used referenda to decide on whether to enter the European Union, to introduce the Euro, or to decide on European constitutional proposals. By far the largest number of referenda has been undertaken in Switzerland.

Most representative democracies do not give their citizens the right to decide on matters of content; this is entirely left to the professional politicians. An example is Germany. Though its constitution (called Grundgesetz) would in principle allow referenda, no referenda have been admitted or undertaken at the federal level. At the state and communal level there are some efforts to introduce direct democratic elements. But up to now, the voters have few possibilities. Direct democratic elements are also absent in most international and supra-national organizations. In the United Nations system it is completely absent, in the European Union nearly so.

These are the strengths of referendum democracy:

- First of all, as democracy means that there is self-determination in politics, it is the very idea of democracy that the citizens are able to decide on matters of content. Representative democracy is at best an indirect and incomplete way to follow the wishes of the voters.

- Referenda are the most effective means to control the politicians. The voters as a collective are difficult to influence, manipulate or corrupt by a politicians in order to serve their ends. It is much simpler to do that with a small group of persons. In representative democracies

\footnotetext{
${ }^{1}$ In most of these States the direct democratic instruments work well. California is an exception, the reason being that the citizens have to decide on too many issues at a time. It is not rare that they are supposed to decide over 40 propositions overtaxing the citizens. In contrast, in Switzerland there are typically 2 issues at the local level, 2 at the cantonal level and 2 at the federal level. The citizens can easily distinguish them because they normally refer to quite different issues.
} 
politicians are controlled only by the elections taking place every four or five years, and in some few cases by high courts. The latter are, however, easier to manipulate than the electorate as a whole, i.e. promises of rewards and threats are more effective. Moreover, the courts members are also members of the "classe politique", and often know, and are personally connected to the politicians in question. They are therefore reluctant to take action against them.

- There is a considerable number of beneficial effects of referenda on economic outcomes. Exploiting the fact that the extent of direct political participation rights differs between the 26 Swiss cantons (and also considering the respective differences in communes) research has identified that in cantons with more extensive direct democratic rights (such as in the canton Basel Landschaft) compared to those with less extensive rights (such as e.g. Geneva)

- public services are provided more efficiently (Pommerehne 1987) \{Pommerehne, 1987 \#52\};

- public debt is lower (Feld and Kirchgässner 1999);

- tax evasion is lower (Frey 1997)

- per capita incomes are higher (Feld and Savioz 1997);

- people are more satisfied with their lives (Frey and Stutzer 2002, Frey 2008).

These results have been reached by keeping a large number of controlling factors constant and by using generally accepted econometric techniques. Similar results have also been reached in comparisons between American States with more or less extensive political participation possibilities of the citizens.

What matters most, however, is that a referendum democracy with citizens as the sovereign exists in reality. The example of Switzerland shows that it is able to work and that it does not lead to bad outcomes. After all, Switzerland is generally acknowledged to be a reasonably well-functioning country ${ }^{2}$ and that its inhabitants state that they have a very high level of life satisfaction ${ }^{3}$.

Direct democracy has, as any other institution existing, also its weaknesses. The following aspects are usually mentioned:

- Citizens are said to be uninterested and uninformed about political issues. This is certainly the case in a representative democracy because the voters cannot exert any influence. A low level of interest and information should be considered to be a rational reaction to the way the political system is organized. For most citizens it makes little sense to get informed as the decisions are anyway taken by their representatives in parliament and government. In contrast, when citizens are able to co-determine on issues of content, they have an incentive to get informed. An analysis (Benz and Stutzer 2004) undertaken across European nations, some of which allowed their

\footnotetext{
2 In the recent ranking of the "Best Country in the World" presented by Newsweek (2010) Switzerland is second after Finland (but it has been shown that this ranking is due to an arithmetic error, and that indeed Switzerland ranks first).

${ }^{3}$ The second highest after Denmark according to the recent Gallup World Survey see Deaton (2008), Frey and Stutzer 2002, Frey 2008.
} 
citizens to participate in referenda on issues related to the European Union, empirically supports this point. Citizens in countries allowing such direct political participation proved to be better informed about political issues than citizens in countries not permitting such participation.

- Citizens are, on average, less well educated than professional politicians. This is certainly true. It may well be argued that it makes sense to have a division of labour between persons specializing in making politics and the rest of society. However, the advantage of the division of labour is strongly reduced by the fact that once elected, and until the next election comes near, they have little interest in knowing the citizens' wishes, nor following them. Moreover, referenda serve to decide basic issues, and not technicalities. In a referendum democracy the politicians have to inform citizens about these basic consideration in which benefits and costs need to be evaluated. To evaluate the benefits and costs is not a matter of education but of preferences, and democracy is that type of regime in which the evaluation of all citizens is to count.

- It may be claimed that the voters often take "wrong" decisions. This charge is fundamentally mistaken because the institution of a referendum democracy accepts the results of the vote (provided it has been taken according to the rules and has not been manipulated), and there is no basis to argue that it is right or wrong. The political elite tends to call decisions wrong if they do not correspond to what they think themselves. But this feeling is irrelevant.

It can, moreover, be pointed out that referendum democracies obviously have not resulted in such bad decisions as to lead to catastrophic mistakes. As pointed out above, the opposite seems to hold: it can well be argued that referendum democracies perform better than representative democracies.

- Referendum democracies are criticized because the decisions are cumbersome and slow. This is to some extent true. The political decision process does not end when the parliament and/or the government has taken a decision but it has to be waited until it is clear whether the citizens want a referendum, and if so, what its result is. This process is little elegant. The right of women to vote has on the federal level indeed been introduced very late (1973) but since then women have reached a strong position in politics. For example, three out of seven members of the Bundesrat, the federal executive, are women (as of August 2010). The voting right of women was introduced at about the same time that in the United States the blacks (and other minorities) got their factual (rather than formal) voting right.

The discussion makes clear that the referendum democracy is far from being an ideal. But this judgment applies to all political regimes. It would be easy to list many shortcomings of representative democracies. What matters is a comparative evaluation. 


\section{Why so few referendum democracies?}

In view of the great advantages of direct democratic elements one wonders why they play such a small role in most countries of the world, even in otherwise staunch democracies. The reason has to do with the incentives of politicians. Giving the citizens the right to have the last say reduces the power and influence of professional politicians. They therefore have a strong incentive to oppose its introduction. This even applies to politicians in Switzerland who try to exploit every opportunity to reduce the scope of direct democratic decisions. Fortunately, the referendum rights are secured in the constitution the politicians cannot unilaterally change.

Direct democratic elements can be introduced from above or below. Introducing referenda on the federal or super-national level has the advantage that the questions at hand are of particular importance, and have therefore been discussed in the media so that the voters tend to be quite well informed. A country could also start at the level of communes in which many decisions are easy to understand for citizens who get the chance to decide and therefore must learn to understand the issues. In some cases governments have used referenda when they were at a loss what to do, or when the pressure from the street was particularly strong. Under these circumstances there is the danger that a referendum becomes a plebiscite in which the government pushes the voters to support the decision they prefer. They project the image that there are terrible consequences if the plebiscite is not approved which leaves the voters little option than to go along. Plebiscites therefore differ from referenda where the citizens have a serious option between alternatives, and the government has to put the decision into reality.

Direct democratic elements may be taken to be an innovation in countries solely based on political representation. From the point of view of the countries already having, and using, referenda they are far from being an innovation. Rather, they could be looked at as a necessary ingredient for democracy in the $21^{\text {st }}$ century. In the following, other innovations in democracy are considered. The next section shortly discusses some possibilities with respect to voting rules and procedures.

\section{Innovative voting rules and procedures}

In most democracies, voting is restricted to citizens of the country. This need not be so. It is well possible to give voting rights to foreigners who have lived in the country for some time. It might also be discussed whether some sort of balance should be applied with respect to age. As the young can only vote at a particular age (often 18, but sometimes 16 or 21), one could establish that the old lose their voting right at, say, age 80 . A more general issue is how to make the interests of future generations felt in the political process. One possibility would be to give the parents additional votes according to the number of children. Another - so far not discussed - possibility would be to give younger voters (e.g. those of age 18 to 38) the right to determine the old age pensions of the politicians. The latter would then become an incentive to specially care for the interests of the younger part of the citizenry. Yet another innovation would give the voting right for restricted periods only. If, for instance, a manager works for five years in a foreign country, he or she would be allowed to vote there, but upon leaving would loose this privilege. 
Originally, direct political participation rights were exercised in citizens' assemblies ${ }^{4}$. In almost all representative democracies the citizens are required to cast their vote at a particular day and within particular hours in a voting booth. In some democracies voting by mail is possible (e.g. in Switzerland). The next step would be electronic voting which so far has only been introduced sparingly and as an experiment. An extreme variant would be to give citizens the possibility to decide political issues all the time and for all issues. It should be carefully considered whether such an electronic democracy is desirable. It seems that the important interaction between the politicians and the citizens before voting would be undermined.

Another innovative extension of democracy would be to elect the delegates in international organizations by the citizens. This could also be the case for national institutions independent from government, such as the members of courts ${ }^{5}$, the governing board of the central bank and the management of functional jurisdictions ${ }^{6}$.

\section{Innovations beyond traditional democracy}

So far, various extensions have been discussed serving to renew the type of democracy currently existing. But it is also possible to go beyond and to suggest major changes. With respect to decision rules, "voting by veto” (Mueller 1978) or voting by imposing a tax on negative externalities produced (Tideman and Tullock 1976).

I want to direct attention on voting rules using a random mechanism. A great advantage of using lot or probabilities is that they are able to reflect the preferences of the citizens more closely than does simple majority voting. An example is "probability majority voting" (Frey 1969). Consider the decision to establish a bridge. It is only possible to build it, or not to build it. According to simple majority voting, the bridge would be built if 51\% approve, even if $49 \%$ of the voters oppose it. The innovation is to build the bridge with a probability of $51 \%$. This can be done by putting 51 green balls and 49 red balls into an urn and then to randomly choose one ball. If it is green, the bridge should be built, if it is red, it should not be built. But the bridge has been built with a probability of 51\%. One major advantage of this proposal is that the majority and minority get exactly the weight they deserve, while with majority voting the interests of the minority a totally neglected. This procedure has also been applied to point voting (Intriligator 1973).

Demarchy (Burnheim 2006, Léon 1988) uses a random mechanism to select members of parliament (and other institutions). By lot citizens are selected to serve in parliament. This guarantees that the members of parliament correspond exactly to the citizenry. Nobody has an incentive to spend time, effort and money ${ }^{7}$

\footnotetext{
${ }^{4}$ This is still the case in many communes and in the few remaining Swiss

Landsgemeinden.

${ }^{5}$ This possibility exists in the United States and in Switzerland.

${ }^{6}$ See the proposal to establish FOCJ, or "Functional, Overlapping, Competing Jurisdictions” in Frey and Eichenberger (1999).

${ }^{7}$ The huge expenditures of persons wanting to enter parliament or having an executive position has become a problem in many democracies, especially in the United States.
} 
to be elected, and nobody has an incentive to use corruption in order to manipulate the composition of parliament. To use lots in politics has supported by Aristotle in his Politeia, book 4. Demarchy has indeed been used in classical Athens, in the republic of Venice to select the doge, today for citizens' assemblies in Canada and Australia, as well as for juries and internet governing bodies.

\section{Conclusions}

Democracy is one of the great ideas of mankind, and arguably the greatest of human innovations. As an idea, and not necessarily as a practice, democracy has been extremely successful. Every political regime wants to be called democratic. This development has a downside. The idea of democracy has become "sacred" and has been made immune against criticism and further developments. This is unfortunate because the very idea of democracy is that it is a living and dynamic institution in constant need of change and improvement.

Direct democratic elements are such a development. It has been argued that it has many desirable features and that it therefore should be the democracy of the $21^{\text {st }}$ century.

Yet it is possible to go further. Democracy can be extended by introducing new voting rules, in particular opening the voting rights to new persons. Similarly, voting procedures can go beyond current voting at one particular day and closely described hours. The internet opens new possibilities which should be seriously considered. The most innovative extension of democracy uses random mechanisms enabling a fuller representation of views and persons. Thus, "probability majority voting” takes into account the interests of voters in the minority. Demarchy allows an exact representation of the citizenry in parliament and the executive. Each of these democratic innovations also has negative aspects. Demarchy, for instance, solely focuses on full representation of the citizenry but disregards that best suited persons should be selected as politicians. There is thus a trade-off between representation and suitability to be faced.

This paper does not argue that these innovations should be introduced. Rather, they serve to open the discussion by suggesting new ideas.

\section{Literature}

Benz, Mathias and Alois Stutzer (2004). Are voters better informed when they have a larger say in politics? Public Choice 119: 31-59.

Burnheim, John (2006). Is democracy possible? The alternative to electoral politics 2nd edition, Sydney University Text and Imaging Service (SETIS).

Frey, Bruno S. (1969) Wahrscheinlichkeiten als gesellschaftliche Entscheidungsregel 
Wirtschaft und Recht 21: 3-15.

Frey, Bruno S. (1994). Direct democracy: Politico-economic lessons from Swiss experience. American Economic Review 84: 338-348.

Frey, Bruno S and Alois Stutzer (2002). Happiness and Economics. Princeton:

Princeton University Press.

Frey, Bruno S. (2008). Happiness. A Revolution in Economics. Cambridge, Mass. and London: MIT Press.

Newsweek (2010). The Best Countries in the World. August 23 \& 30:32-40. 